\title{
Analysis of Improvement of Pregnancy During Pandemic at Pondok Gede Health Centre Bekasi City in 2021
}

\author{
Andi Julia Rifiana ${ }^{1 *}$, Ratna Sari \\ 1,2Midwifery Department, Universitas Nasional Jakarta; andi.rifiana@civitas.unas.ac.id (Corresponding Author)
}

\section{Article Info: \\ Submitted: \\ 06-04-2021 \\ Revised: \\ 27-05-2021 \\ Accepted: \\ 31-05-2021}

DOI:

https://doi.org/10.53713/nhs.v1i1.20

\section{(c) (i) (2)}

This work is licensed

under CC BY-SA License.

\begin{abstract}
Pregnant women at Pondok Gede Health Center experienced an increase in visits to pregnancies of at-risk mothers in 2019 which consisted of 23 people, while in 2020 there were 103 people. The main cause of pregnancy at risk age is the noncompliance of family planning, the work of WFH during the pandemic. Efforts to reduce risky age pregnancies, BKKBN urges couples of reproductive age to plan pregnancy, using contraception (condoms). The analysis of the causes of increased pregnancy at risk is a large picture of pregnant women with maternal age $\leq 20$ years and $\geq 35$ years. This research aimed to determine the analysis of the causes of increased pregnancies at risky ages during the pandemic at Pondok Gede Health Center, Bekasi City in 2021.Research analytic by using the method cross-sectional. Sample were82 respondents with accidental sampling technique. The instrument research was a questionnaire. Data analyzed using univariat and bivariat by test statistic chi square. The result is pregnant women with age $\geq 35$ years were $75.6 \%$, who had good knowledge was $54.9 \%$. who have access to family planning services was $53.7 \%$, who were planned was $56.1 \%$, anxiety was $54.9 \%$, who have unmet need pregnancy was $51.2 \%$, and who work WFH was $72.0 \%$. There was no significant relationship between knowledge, access to family planning services, planned pregnancy, anxiety, unmet need pregnancy, work during the pandemic and pregnancy at the age of mothers at risk at Pondok Gede Health Center, Bekasi City with a $p$ value $<0.05$.
\end{abstract}

Keywords: pregnancy; at risk age; Covid pandemic.

\section{INTRODUCTION}

During the Indonesian pandemic, there were more than 400,000 unplanned pregnancies. Some health and gynecological clinics were closed during the large-scale social restrictions (PSBB) to prevent the spread of Covid-19. According to the BKKBN, this makes it difficult for the community to access KB/Family Planning services. During the pandemic period of increasing pregnancy rates at the beginning of next year, more than 420,000 newborns. The estimate is base on 10 percent of the 28 million families experiencing birth control difficulties. The Central Statistics Agency projects that in 2020 the population of Indonesia will increase by $271,066,000$ people. There are at least about 4.8 million new births every year in Indonesia (BKKBN, 2020).

The pregnancy rate in the West Java Province during the pandemic has increased. The highest pregnancy rate is in the West Java region, namely in Bandung as many as 2,210 people, Cirebon as many as 2,210 people, Garut as many as 1,950 people, and Tasikmalaya many as 1,205 people (Ridwan Kamil, 2020). Based on data from the first visit of pregnant women to health care facilities recorded at the Bekasi Health Office, the 2019 Coronavirus disease (COVID19) pandemic did not affect the pregnancy rate in Bekasi Regency, West Java. On the contrary, even the number of pregnant women has decreased by about 8.4 percent compared to last year. Throughout March 2020, there were 6,551 people, while in the following month, there were 6,400 people. Meanwhile, in March and April last year, the numbers were 7,075 and 7,052 , respectively. In total, in two months last year, the pregnancy rate reached 14,127 people, while two months ago (March and April), 12,951 pregnant women (Bekasi Regency Health Office, 2020).

Pondok Gede Health Center Bekasi is one of the first-level health facilities by serving 24-hour deliveries and providing comprehensive services, especially in maternal and child services (KIA) monthly ANC services for 200 people, and visits by pregnant women with maternal age at risk for the period October - December age 20 years old as many as 20 people and age 35 years as many as 83 people. There are ten maternity patients per month, ten postpartum patients, ten newborns per month. Based on interviews conducted with 15 pregnant women with a risk age of 20 years and 35 
years. 11 out of 15 pregnant women stated that the mother was ready for pregnancy during this pandemic, and there were no problems in her health, so the mother considered herself not at risk. At this time, more activities at home due to the implementation of work from home for employees. During this pandemic, mothers stated that they did not use family planning because they were afraid to leave the house, making their contraceptive needs unfulfilled (unmet need).

\section{METHOD}

This research is analytic, meaning that it is a study that aims to see a relationship using the cross-sectional method, namely the type of cause (independent) and effect (dependent) variables measured at the same time (Notoatmodjo, 2018). In this study, the population in this study was pregnant women who did ANC checks at the UPTD Puskesmas Pondok Gede Bekasi City, the period from October to December 2020 as many as 103 people. The sample is a small part of the population's number and characteristics that consider representing the population (Omega, 2017). The sampling method in this study was using accidental sampling. The sample in this study was some pregnant women with gestational age and 20 years and 35 years in the working area of Pondok Gede Health Center Bekasi City in January 2021. The number of samples was 82 respondents. The sampling method in this study was using accidental sampling at the Pondok Gede Health Center, Bekasi City. Data collection begins in January 2021.

\section{RESULT}

Table1. Univariate Analysis $(\mathrm{n}=82)$

\begin{tabular}{lll}
\hline \multicolumn{1}{c}{ Variable } & $\mathrm{n}$ & $\%$ \\
\hline Risky of Pregnancy & & \\
Yes & 68 & 82.9 \\
No & 14 & 17.1 \\
\hline Knowledge & & \\
$\quad$ Good & 45 & 54.9 \\
$\quad$ Less & 37 & 45.1 \\
\hline KB Service Access & & \\
$\quad$ Exist & 44 & 53.7 \\
$\quad$ Not exist & 38 & 46.3 \\
\hline Pregnancy Planning & & \\
$\quad$ Planned & 46 & 56.1 \\
$\quad$ Unplanned & 36 & 43.9 \\
\hline Anxiety & & \\
Anxious & 37 & 45.1 \\
$\quad$ Not Anxious & 45 & 54.9 \\
\hline Unmed Need Pregnancy & & \\
$\quad$ Fulfilled & 40 & 48.8 \\
$\quad$ Not fulfilled & 42 & 51.2 \\
\hline Work during the pandemic & & 72.0 \\
$\quad$ WFH & 59 & 28.0 \\
$\quad$ WFO & 23 & 100 \\
\hline$\quad$ Total & 82 & \\
\hline
\end{tabular}

Based on table 1, it knows that from 82 respondents, pregnant women who are at risk are 68 respondents $(82.9 \%)$, and pregnant women who are not as many as $14(17.1 \%)$, pregnant women with good knowledge are 45 respondents $(54.9 \%)$, and pregnant women who have less knowledge as many as 37 respondents $(45.1 \%)$. Pregnant women with access to family planning services are 44 respondents $(53.7 \%)$, and pregnant women who do not have access to family planning services are 38 respondents (46.3\%). Planned pregnant women were 46 respondents (56.1\%), and unplanned pregnant women were 36 respondents $(43.9 \%)$. There were 37 respondents $(45.1 \%)$ at risk of anxious pregnant women, and 45 respondents $(54.9 \%)$. Pregnant women at risk that met were 40 respondents $(48.8 \%)$, and pregnant women at risk not met as many as 42 respondents (51.2\%). 59 respondents (72.0\%) and at-risk pregnant women had WFO jobs, as many as 23 respondents (28.0\%). 
Table 2. Bivariate Analysis

\begin{tabular}{|c|c|c|c|c|c|c|c|}
\hline \multirow{2}{*}{ Variables } & \multicolumn{4}{|c|}{ Pregnancy at Risk } & \multicolumn{2}{|c|}{ Total } & \multirow{2}{*}{ p-value } \\
\hline & $\mathrm{n}$ & $\%$ & $\mathrm{n}$ & $\%$ & $n$ & $\%$ & \\
\hline \multicolumn{8}{|l|}{ Knowledge } \\
\hline Good & 35 & 77.8 & 10 & 22.2 & 45 & 100 & \multirow{2}{*}{0.241} \\
\hline Less & 33 & 89.2 & 4 & 10.8 & 37 & 100 & \\
\hline \multicolumn{8}{|l|}{ KB Service Access } \\
\hline Exist & 35 & 79.5 & 9 & 20.5 & 44 & 100 & \multirow[t]{2}{*}{0.558} \\
\hline Not exist & 33 & 86.8 & 5 & 13.2 & 38 & 100 & \\
\hline \multicolumn{8}{|l|}{ Pregnancy Planning } \\
\hline Planned & 39 & 84.8 & 7 & 15.2 & 46 & 100 & \multirow[t]{2}{*}{0.769} \\
\hline Unplanned & 29 & 80.6 & 7 & 19.4 & 36 & 100 & \\
\hline \multicolumn{8}{|l|}{ Anxiety } \\
\hline Anxious & 31 & 83.8 & 6 & 16.2 & 37 & 100 & \multirow[t]{2}{*}{1.000} \\
\hline Not Anxious & 37 & 82.2 & 8 & 17,8 & 45 & 100 & \\
\hline \multicolumn{8}{|l|}{ Unmed Need Pregnancy } \\
\hline Fulfilled & 31 & 77.5 & 9 & 22.5 & 40 & 100 & \multirow[t]{2}{*}{0.248} \\
\hline Not fulfilled & 37 & 88.1 & 5 & 11.9 & 42 & 100 & \\
\hline \multicolumn{7}{|l|}{ Work during the pandemic } & \multirow{3}{*}{1.000} \\
\hline WFH & 49 & 83.1 & 10 & 16.9 & 59 & 100 & \\
\hline WFO & 19 & 82.6 & 4 & 17.4 & 23 & 100 & \\
\hline Total & 68 & 82.9 & 14 & 17.1 & 82 & 100 & \\
\hline
\end{tabular}

Based on table 2 , it is known that of the 82 risky pregnant women who have good knowledge there are 35 people $(77.8 \%)$ and those who have less knowledge are 33 people (89.2\%) while the non-risk pregnant women who have good knowledge are 10 people $(22.2 \%)$ and who have less knowledge there are 4 people $(10.8 \%)$ with $p$ value $=0.241(p$ value $<0.05$ ) which means there is no significant relationship between knowledge and pregnancy at maternal age risky; There are $35(79.5 \%)$ at risk pregnant women who get access to family planning services and 33 people (86.8\%) who do not get access to family planning services, while there are 9 people who are not at risk who get access to family planning services $(20.5 \%)$ and there were 5 people $(13.2 \%)$ who did not get access to family planning services with $p$ value $=$ 0.558 ( $p$-value < 0.05 ) which means that there is no relationship between access to family planning services and pregnancy at risky maternal age; Pregnant women at risk whose pregnancies were planned were 39 people (84.8\%) and 29 people were unplanned $(80.6 \%)$ while the pregnant women were not at risk whose pregnancies were planned there were 7 people $(15.2 \%)$ and those who were not prepared. There are 7 people $(19.4 \%)$ with $p$ value $=0.769(p$. value $<$ 0.05 ) which means there is no relationship between access to family planning services and pregnancy at risky maternal age; There are 31 risky pregnant women (83.8\%) who experience anxiety and 37 people (82.2\%) who are not anxious, while for non-anxious pregnant women who experience anxiety there are 6 people $(16.2 \%)$ and not anxious there are 8 people $(17.8 \%$ ) with a value of $p=1.000$ (p.value $<0.05$ ), which means that there is no relationship between anxiety and increased pregnancy at risky maternal age; Pregnant women at risk met 31 people $(77.5 \%)$ and 37 people $(88.1 \%)$ were not met, while pregnant women did not meet at risk there were 9 people (22.5\%) and not fulfilled there were 5 people (11 $.9 \%$ ) with $p$ value $=0.248(p$. value $<0.05)$, which means that there is no relationship between unmet need pregnancy and pregnancy at risky maternal age; Pregnant women at risk of working WFH there are 49 people $(83.1 \%)$ and working WFO there are 19 people (82.6\%) while pregnant women are not at risk of working WFH there are 10 people $(16.9 \%)$ and working WFO there are 4 people $(17.4 \%$ ) with a value of $p=1.000$ (p.value $<0.05$ ), which means that there is no relationship between work during the pandemic and pregnancy at risky maternal age.

\section{DISCUSSION}

Notoatmodjo (2018) says knowledge results from knowing about a specific object after sensing it through the five human senses, including sight, hearing, smell, taste, and touch. Humans get knowledge mainly from the eyes and ears and form a person's action or behavior with this knowledge. Notoatmodjo (2018) said that formal and non-formal education could provide information that has short-term or long-term effects so that it can produce increased knowledge. If a person gets a lot of information, his knowledge will be more comprehensive. If his knowledge is broad, it will be easy for the person to change behavior, exceptionally healthy behavior from negative to positive. According to researchers at the Pondok Gede Health Center Bekasi City, the bivariate results showed no relationship that most pregnant women had good knowledge about pregnancy at risky ages. 
Pregnant women already know information about risky pregnancies. Still, there are no problems with their pregnancy so that pregnant women assume she is not at risk if she gets pregnant during a pandemic. The results of this study are not by the theory of the Indonesian Ministry of Health (2020), which states that access to family planning services hamper so that it can cause acceptors to drop out of family planning or drop out of family planning participation. If this condition not anticipates, it will cause various problems in the future, including increasing pregnancy rates. According to the opinion of researchers at the Pondok Gede Health Center, Bekasi City. The bivariate results showed no pregnancy relationship occurred in pregnant women who did not have access to family planning services; this happened because there was also access to family planning services, only that the health workers did not receive services due to this pandemic period. Medical personnel are more careful in providing services to patients. So that this research has no relationship with access to KB services. The Indonesian Ministry of Health (2020) said that pregnancy is planning by ensuring that it was feasible to get pregnant. After fulfilling the criteria such as EFA age between 20-35 years, have not had children or have children not more than 2, the distance between pregnancies is not less than two years, not anemia, not KEK (upper arm circumference $23.5 \mathrm{~cm}$ ), Height $>145 \mathrm{~cm}$.

According to researchers at the Pondok Gede Health Center, Bekasi City, the bivariate results showed that most of the increase in pregnancies that occurred in unplanned pregnant women had a greater chance than pregnant women who planned pregnancy. There were still many couples of childbearing age who had postnatal family planning giving birth so that in this study, there was no relationship between planned pregnancies and the occurrence of pregnancies at risky ages.

Dorland (2010) says the word anxiety or anxiety is an unpleasant emotional state. In the form of psychophysiological responses that arise in anticipation of an unreal or imaginary danger. Cause by an intrapsychic conflict that not directly realize. Sutejo (2018) Anxiety is a feeling of fear of something happening caused by anticipating danger and is a signal that helps individuals prepare to deal with threats. The influence of demands, competition, and disasters that occur in life can impact physical and psychological health. One of the psychological effects is anxiety or anxiety. According to researchers at the Pondok Gede Health Center, Bekasi City, from the bivariate results.

Most pregnant women have no relationship between anxiety and pregnancy at risky ages because pregnant women at risk and productive age do not feel anxious about their pregnancy. After all, their pregnancy has no problems that make pregnant women don't feel anxious. Isa, M. (2009) said Unmet need could define as a group whose contraceptive needs have not met. Including all men or women of childbearing age who are married or living together and consider sexually active, do not use contraceptive methods, either who do not want to have children. Again or delaying the next birth. Demographic and socioeconomic factors cause factors that affect unmet needs in Indonesia. Several studies have revealed the factors that cause unmet need, including lack of knowledge about family planning, lack of husbands' support, and culture that is still firmly held by couples of childbearing age.

According to researchers at the Pondok Gede Health Center, Bekasi City, from the bivariate results, most pregnant women experienced the fulfillment of contraceptive needs in productive couples. These productive couples use many IUDs and implant contraception to meet their contraceptive needs, and there is no relationship between unmet need pregnancy and pregnancy at risky ages. Notoatmodjo (2018) said that work status or socioeconomic level would also affect mothers for pregnancy during the pandemic. According to the theory of employment status and socioeconomic level, describe a person's level of life in society or determined by employment and income variables because these can affect aspects of life, including health care. Families with jobs with good economics can check their pregnancy regularly, plan delivery at health workers. The Ministry of Finance (2020) said that working from home or work from home, which carries out during the pandemic period, worked remotely, more precisely, working from home. Workers do not need to come to the office face to face with other workers. Work from home is already familiar to freelancers; they call it remote work or remote working. Work from home and remote working makes no difference, only the terms; the only difference is the company's rules. Some apply regular working hours from 8 am to $4 \mathrm{pm}$ or free working hours as long as doing the work, and communication is always fast. According to researchers at the Pondok Gede Health Center, Bekasi City, from the bivariate results. Most of the wives experience work from home, but in this case, not all husbands work from home; this is also a lot of wives who still work in the office or trade so that the work is not related to pregnancy at risk. 


\section{CONCLUSION}

Most of the pregnant women were at the age of $82.9 \%$ at risk. There was no significant relationship between knowledge, access to family planning services, planned pregnancy, anxiety, unmet need pregnancy, and work from home with pregnancy at risky maternal age with $p$-value $<0.05$. Health workers will bring the mobile family planning service program closer to the posyandu or door to door so that it is easier to access family planning services during a pandemic like this. In addition, health workers, such as doctors, nurses, and midwives, increase promotion and create family planning programs regarding family planning used during the pandemic.

\section{REFERENCES}

BKKBN. (2020). Masa Pandemi di Indonesia Ada Lebih dari 400.000 Kehamilan, https://www.kompas.com/sains/read/2020/05/20/110300923/lebih-dari-400.000-kehamilan-baru-terjadi-selama-pandemi-diindonesia?page=all, Accessed 10 November 2020.

Crosbie, T., \& Moore, J. (2004). Work-life balance and working from home. Social Policy and Society, 3(3), $223-233$.

Dorland WA, Newman. (2010). Kamus Kedokteran Dorland edisi 31. Jakarta: Penerbit Buku Kedokteran EGC. p. $702,1003$.

Dinkes Kabupaten Bekasi. (2020). Data Kunjungan Pertama Ibu Hamil ke Fasilitas Pelayanan Kesehatan, https://www.pikiranrakyat.com/jawa-barat/pr-01398 403/selama-pandemi-covid-19-ibu-hamil-di-kabupaten-bekasi-mencapai-1295 1, Accessed 10 November 2020.

Harahap, S.S. (2015). Analisis Pengetahuan. Rajawali Pers: Jakarta.

Haryati, N. (2012). Buku Acuan Nasional Pelayanan Kesehatan Maternal dan Neonatal. Bumi Aksara: Jakarta.

IBI. (2020). Situasi Pelayanan Kebidanan pada Masa Pandemi Covid - 19 dan Memasuki Era New-Normal, https://Www.Ibi.Or.Id/Media/Materi\%20Webina r\%20IBI\%20-\%20USAID\%20Jalin\%20Covid19/Seri\%205\%20\%2010\%20Ju ni $\% 202020 /$ PDF\%201\%20Emi\%2010\%20Juni\%20USAID\%20Jalin\%20\%20SITUASI\%20PELAYANAN\%20KB\%20PADA $\% 2$ OMASA\%20PANDEMI\%20COVID-19\%20\%26\%20ERA\%20NEW\%20NORMAL\%20-Compressed.Pdf, $\quad$ Accessed 11 November 2020.

Isa, M. (2009). Determinan Unmet need Keluarga Berencana di Indonesia: Analisis

Kamil, R. (2020). Angka Kehamilan di Wilayah Provinsi Jawa Barat saat Pandemi, https://jurnalgarut.pikiran-rakyat.com/jawabarat/pr-33572083/angka-kehamil banyak?page=2, Accessed 10 November 2020.

Kemenkes. (2020). Coronavirus Disease-2019 (COVID19), https://www.kemkes.go.id/article/view/20030400008/FAQCoronavirus.html, Accessed 22 November 2020.

Kemenkeu. (2011). Keputusan Menteri Keuangan Nomor 152/KMK.9/2011, https://www.djkn.kemenkeu.go.id/artikel/baca/13014/Bekerja-dari-Rumah-Work-From-Home-Dari-Sudut-Pandang-UnitKepatuhan-Internal.html, Accessed 20 January 2020.

Kusmiyati, Y. (2010). Asuhan Kehamilan. Titramaya: Yogyakarta.

Lebel, C., Mackinnon, A., Bagshawe, M., \& Lianne Tomfohr-Madsenb, G.G. (2020). Elevated depression and anxiety symptoms among pregnant individuals during the COVID-19 pandemic. Journal ofAffective Disorders, 277, 5-13.

Manuaba, I.B.G. (2010). IImu Kebidanan, Penyakit Kandungan dan KB untuk Pendidikan Bidan, $2^{\text {nd }}$ ed. EGC: Jakarta.

Notoatmodjo, S. (2014). IImu Perilaku Kesehatan. Rineka Cipta: Jakarta.

Notoatmodjo, S. (2018). Metodologi Penelitian Kesehatan, Cet. 3. Rineka Cipta: Jakarta.

Omega.D.R. (2017). Statistika untuk IImu Kesehatan: Teori dan Aplikasi (SPSS). Wahana Resolusi: Yogyakarta.

Sugiyono. (2014). Metode Penelitian Pendidikan Pendekatan Kuantitatif, Kualitatif, dan R\&D. Alfabeta: Bandung.

Sutejo. (2018). Keperawatan Jiwa, Konsep dan Praktik Asuhan Keperawatan Kesehatan Jiwa: Gangguan Jiwa dan Psikososial. Yogyakarta: Pustaka Baru Press. 